\title{
Article
}

\section{Types of Gameplay in Newsgames. Case of Persuasive Messages about COVID-19}

\author{
Julio Merchán-Romero ${ }^{1}$ and Angel Torres-Toukoumidis $1,2, *$ (D) \\ 1 Gamelab Research Group, Universidad Politécnica Salesiana, Cuenca 010105, Ecuador; \\ jmerchanr1@est.ups.edu.ec \\ 2 Social Science Knowledge and Human Behavior Department, Universidad Politécnica Salesiana, Cuenca \\ 010105, Ecuador \\ * Correspondence: atorrest@ups.edu.ec
}

check for

updates

Citation: Merchán-Romero, Julio, and Angel Torres-Toukoumidis. 2021. Types of Gameplay in Newsgames. Case of Persuasive Messages about COVID-19. Journalism and Media 2: 746-757. https://doi.org/10.3390/ journalmedia2040044

Academic Editors: José Rúas Araujo, John P. Wihbey and

Daniel Barredo-Ibáñez

Received: 8 September 2021

Accepted: 22 November 2021

Published: 24 November 2021

Publisher's Note: MDPI stays neutral with regard to jurisdictional claims in published maps and institutional affiliations.

Copyright: (C) 2021 by the authors. Licensee MDPI, Basel, Switzerland. This article is an open access article distributed under the terms and conditions of the Creative Commons Attribution (CC BY) license (https:/ / creativecommons.org/licenses/by/ $4.0 /)$.

\begin{abstract}
Currently, independent video games have been presented as an alternative to approach the development of a ludic typology called newsgames in which, distancing themselves from the interests of the entertainment industry, a series of games related to the pandemic are presented. From here, we seek to examine the gameplay elements and persuasive messages of 17 "indie games" in the context of COVID-19, categorizing them according to types of newsgames and determining any patterns present among them. The results manifest a tendency towards tabloid newsgames, which are characterized by dealing with sensational, direct, and immediate information using humor and exaggeration to convey messages, which, in this case, focuses on biosafety measures such as hand washing, the use of alcohol for sanitation, and social distancing. On the part of the gameplay elements, a linear narrative is maintained, but it is mainly a sum of achievements to reach the game's objectives. In short, independent newsgames are formalized as an instrument of diversification in media realities that allow for the presenting of information in an alternative way without depending on editorial lines within a crisis context, as has been the case during the pandemic.
\end{abstract}

Keywords: narratology; indie games; COVID-19; audiovisual platforms; newsgames

\section{Introduction}

During the last decades, we have witnessed the advance of different information and communication technologies, which have shown a constant evolution in the digital world, allowing for greater access to multiple fields of information and contributing to different areas such as education or leisure. According to Requena and McMullin (2015), technological knowledge innovations and experiences favor the development of inclusion; in this way, virtuality comes to play a leading role in the scene of resources that benefit the acquisition of knowledge and reduce the lock-in kind of thinking that has caused the current pandemic (Ferreira and Borges 2020).

Regarding this, Alarcia (2015) adds that video games are a valuable tool for "digital migrants", or people who did not grow up immersed within the digital ecosystem, providing them with an alternative way of generating a gradual understanding of this new form of interaction. Belli and Olivé (2008) express that video games have served as a didactic tool to afford reflective thinking management to generate a particular interpretation of its content. The use of video games is presented as an exemplifying element for entertainment actions, and through their ludic components, they produce a motivating and attracting effect to their users (Romero-Rodríguez and Torres-Toukoumidis 2018). In short, knowing the positive impact that video games contain, their applicability towards specific contexts produces current debates, such as how the pandemic has been addressed in video games and what this tells us about the importance of video games in media, allowing us to formalize the following question: what is the importance of video games within the media? To 
answer this question, the incipient relationship between them is composed of two premises: media literacy and newsgames.

To answer the video games-media literacy link, it would be worthwhile to contextualize the ideas of Gavoto et al. (2020), who admit that, during the pandemic, video games have had a distracting effect on young people, being a form of escape from a certain situation for the person involved, reaching excessive levels approaching degrees of addiction. Video games can also be configured as a social scourge that promotes addictions, sedentary lifestyles, and harmful behaviors to the welfare of young people (Torres Fernández et al. 2021).

Moreover, video games promote playful media competences, establishing a better understanding of information between natives, digital migrants, and new generations, with new social situations making visible some turning points, such as interactivity (Torres-Toukoumidis et al. 2019) and an individual's ability to interpret and extrapolate it for a better experience of information, thus making for richer, more plural, deeper, and more complex comprehension (Igado et al. 2013).

In fact, for video gamers who belong to the digital era, interaction develops the potential for a media literacy which takes behaviors generated in digital media as key tools for acting diligently during confinement (Hobbs 2021).

The second premise that links video games with the media is newsgames. Newsgames are a subtype of serious games that go beyond entertainment-that do not necessarily transmit a political message, but rather the implications of a news story. Any transmission of news is editorialized, but newsgames do not need to be received exclusively as political opinion articles (Sicart 2008). Moreover, newsgames have the specific function of persuading a given audience for a while, providing contextual information in the same way as traditional documentaries and journalistic reports; also, due to the didactic quality that video games have, they bring arguments in favor of participation in debates of public interest (Torres-Toukoumidis and Romero-Rodríguez 2018).

In short, newsgames are determined by a timeline (Gómez García and Sierra 2013), even more so when their existence depends on a second factor, which, in this scenario, would be a health crisis, making them precisely a tool for illustrating variants of a disease to advocate for user-presence and experimentation in a virtual medium, but with efficient data that support and give a background to the informative video game experience.

\section{Literature Review}

\subsection{Video Games as a Form of Interaction in the Pandemic}

The learning experience found in digital game themes can even become a better way to reach new generations than traditional media-than press, radio, and television-because it allows for greater versatility when it comes to addressing the experiences in a video game and its interpretation of a real situation. For this, the development of the user's skills and abilities are intimately linked to the intention of managing information in video games, which enhances the user's deductive skills (Marín Gutiérrez et al. 2018).

The existing relationship between video games and the media, in Latin American contexts, does not usually make great contributions to the conceptualization of a video game as a didactic tool, unless such video games lack the determining ludic components or are addressed by didactic objectives which have a clearly determined use. Thus, the question arises: how can video games be relevant to the understanding of a serious topic such as the pandemic? Moreover, what characterizes a video game that can foster the right kind of behaviors and reactions in the midst of a global pandemic?

From a standardized perspective of information transmission, participating in the game is part of the media. Playful virtual environments implement the basic skills for identifying types of content, and in this way, the use of games could be prioritized as an explanatory process, helping to differentiate between the varied information generated by the media (Montes et al. 2018). 
From this point, it can be observed that video games can provide approaches for learning and receiving information, conveying to users the effects of a pandemic and its repercussions. Video games can also act as a preventive and therapeutic gadget, where the intervention of video games can be considered as a channeling tool for possible situations of anxiety or stress observed during the confinement of the first months of the pandemic (Costumero 2021). The different ways of approaching the subject of health in times of crisis encourage the constant use of visual acuity and concentration which allows for a greater interpretation of the information shown. On the other hand, for the independent or indie creators, the reason why these video games have a greater impact is their correspondence to pieces of news that depend on circumstantial scenarios. This makes their thematics self-sustainable, as the socialization of users within the virtual environment develops and is constantly updated (Marín and García 2005). This, as in the case of games about the pandemic, they become health games (Gekker 2012).

\subsection{Newsgames and Pandemic}

Generally, video games have been proximal to a representation of fantasy, leisure and entertainment; therefore, the connection between journalism and games can be difficult to understand, especially because journalism tries to get closer to the facts by stimulating the assimilation of information and learning through a framework of quality and professionalism in the dissemination of news manifested in the media landscape (Smith et al. 2020). Meanwhile, games try to address a trivial setting via parallel realities. Then, its combination formulates the notion of newsgames that, over the pandemic situation, generate a special dimension of the setting. De Santis and Armendáriz (2020) focus their research on mobile newsgames-Plague Inc., Outbreak, Virus Antidote, Modibot Inc., and Idle Plague- that are dedicated to raising public awareness about potential pandemics. In particular, Bogost et al. (2012) state that government agencies in the United Kingdom in 2009 created the newsgame Killer Flu as a preventive measure to avoid the spread of the avian flu. In the same circumstance, the National Institute of Applied Sciences in Toulouse, France, designed Superflu and Flucorp Inc. in 2010 to understand vaccine production and the potential eradication of the virus (Ohannessian et al. 2016).

Returning to the COVID-19 situation, there is no extensive academic literature on the use of newsgames; however, we can highlight the study of Gómez-García and Carrillo-Vera (2020), in which they mention games made by news agencies, universities, and associations to combat disinformation. Highlighted among the newsgames used in the analysis is Factitious: Pandemic Edition.

Complementarily, Sierra and Redondo (2020) mention that adding People of the Pandemic and COVID-19 Trivia facilitates understanding and awareness of the impact of a health alert.

In summary, the innovative nature of this research focuses on assessing the independent games linked to the pandemic, according to the types of information and narratological elements implemented in each of their interfaces, to determine their involvement, use, and the ludic characterizations within their narrative correspondences.

\section{Methodology}

General objective: To analyze ludic narratives applied in indie video games during the COVID-19 pandemic.

Specific objectives:

SO1: To categorize the types of information addressed by indie newsgames about the COVID-19 pandemic.

SO2: To examine narratives in gaming platforms of newsgames related to the COVID19 pandemic.

The approach of this research is qualitative-inductive, starting from specific reasoning about indie games connected to the COVID-19 pandemic, to lead to patterns about the narrative elements they harbor in their gameplay. Complementarily, we proceeded 
through a methodological design presented by Lankoski and Björk (2015) to conduct a qualitative review applied to a formal analysis of the anatomy of video games, organizing, distinguishing, and describing the characteristics of their ludic and narrative principles.

Next, non-participant observation was assumed by not acting directly in the design, distribution, or marketing of indie games about the pandemic, and documentation was applied as a data-collection tool, choosing independent games coming from the platforms Itch.io and Game Jolt (Sampieri et al. 2012), because although there are other ludic repositories, such as Origin, the selected two are considered spaces for the dissemination of services belonging to independent video game developers.

In order to analyze the screening of independent video games on topics based on SARS-COV-2 (COVID-19) on both platforms, we proceeded to search for the keywords "pandemic COVID-19", "COVID-19" and "coronavirus" in their internal search engines, obtaining a total of 17 games (Tables 1 and 2):

Table 1. Video games that belong to Itch.io.

\begin{tabular}{|c|c|c|}
\hline Platform & Itch.io & \\
\hline Version & PC & \\
\hline Title & Creator & Description \\
\hline COVID & Martin Herrera & $\begin{array}{l}\text { The player's mission is being vaccinated and } \\
\text { encouraging vaccination to avoid COVID-19. }\end{array}$ \\
\hline $\begin{array}{l}\text { COVID-19 } \\
\text { Shoot the virus dead! }\end{array}$ & Frebks & $\begin{array}{l}\text { The user must understand the necessary tools for } \\
\text { disinfection and antibacterial care. }\end{array}$ \\
\hline COVID-run & HYdr0g3ndev & $\begin{array}{l}\text { The user's mission is to stay as far away as possible } \\
\text { from contagious agents. }\end{array}$ \\
\hline COVID Cafe & N8Dev & $\begin{array}{l}\text { The player must understand safe distancing, being } \\
\text { instructed on the dangers of crowds and how they } \\
\text { can be prevented by improving efficiency in services } \\
\text { and keeping distance from them. }\end{array}$ \\
\hline $\begin{array}{l}\text { 感染 } \\
\text { COVID-19 }\end{array}$ & Hot Slice & $\begin{array}{l}\text { The player's role is focused on understanding how } \\
\text { the virus acts in an invasive way with little control } \\
\text { capabilities, which implies the importance of } \\
\text { keeping an acceptable social distance. }\end{array}$ \\
\hline Covid-lifestyle & LoneliNerd & $\begin{array}{l}\text { The user must be aware of disinfection methods and } \\
\text { of the reactions to his surroundings to avoid } \\
\text { contagion. }\end{array}$ \\
\hline Covid Escape & Cojkan & $\begin{array}{l}\text { The player must follow disinfection methods when a } \\
\text { person leaves the house and when returning home; } \\
\text { if they do not comply with the process, the character } \\
\text { will be infected. }\end{array}$ \\
\hline COVID Nom Nom & ThomHouse & $\begin{array}{l}\text { The user's mission is to recognize the importance of } \\
\text { cleaning and disinfecting when he/she has been in } \\
\text { social areas, as well as biosecurity rules. }\end{array}$ \\
\hline The COVID-19 & Kartikaygolcha & $\begin{array}{l}\text { The user's mission is to obtain ordinary objects that } \\
\text { are expendable but that still risk infection, while } \\
\text { there are distractions and avoidable risks. }\end{array}$ \\
\hline
\end{tabular}


Table 2. Video games that belong to Gamejolt.

\begin{tabular}{|c|c|c|}
\hline Platform & Game Jolt & \\
\hline Version & PC & \\
\hline Title & Creator & Description \\
\hline $\begin{array}{l}\text { COVID-19 Pandemic } \\
\text { Infection Simulator }\end{array}$ & Lazerbulb_studio & $\begin{array}{l}\text { The user's mission is to observe incorrect } \\
\text { behavior during a pandemic when a } \\
\text { population is infected. }\end{array}$ \\
\hline Covid vs. Vacuna & Jr. Enrique & $\begin{array}{l}\text { The user's role is to avoid being vaccinated } \\
\text { as he observes from the perspective of the } \\
\text { virus, which fights against the greatest } \\
\text { chemical defense to date, the vaccine. }\end{array}$ \\
\hline Covid Game & Guillermodiaz & $\begin{array}{l}\text { In this case, the user is employed as part of } \\
\text { an immune system, which fights against an } \\
\text { intruder, and where it is also shown that, on } \\
\text { certain occasions, the user may also } \\
\text { encounter agents that are indestructible by } \\
\text { the immune system. }\end{array}$ \\
\hline COVID-19 Simulator & Kotaro7 & $\begin{array}{l}\text { The player observes a population that he } \\
\text { himself creates and reacts to different stimuli, } \\
\text { among which is an exemplification of mass } \\
\text { hysteria and mass contagion. }\end{array}$ \\
\hline COVID Courier & Simcoachgames & $\begin{array}{l}\text { The player must demonstrate his knowledge } \\
\text { of different ways to prevent and support the } \\
\text { disease when it attacks the organism, in } \\
\text { order to save the avatar's immune system } \\
\text { based on his responses. }\end{array}$ \\
\hline Coronakiller & Fuzzycat & $\begin{array}{l}\text { The player's mission is to comply with } \\
\text { biosecurity and disinfection rules in order to } \\
\text { save people and prevent contagion. }\end{array}$ \\
\hline Quiz19 & Artelotugamedesign & $\begin{array}{l}\text { The user can see, from an immune system's } \\
\text { perspective, the virus reaching the organism, } \\
\text { observing how the virus is distributed } \\
\text { throughout the organism, unless the immune } \\
\text { system stops it. }\end{array}$ \\
\hline Bio-hazard2020 & Erikajudithtamoturpo & $\begin{array}{l}\text { How to fight the virus while taking measures } \\
\text { against the possibilities of being infected, } \\
\text { and how to defeat the virus by protecting } \\
\text { oneself before being infected. }\end{array}$ \\
\hline
\end{tabular}

These 17 video games were reviewed according to a set of variables evidenced in two groups. The first set of variables responds to the typology of games that, during the first scrutiny, was denoted with a clear inclination to newsgames. Then, this research applied the classification established by Serrano Vázquez (2015):

Editorial games make statements about an event in the same way as do editorials or newspaper cartoons. The author tries to convey a position on a certain topic. The reader must know the context beforehand in order to be able to understand the context in order to be able to take a position together with the game designer.

Tabloid games are unsophisticated; they are based on headlines. They commonly use humor and exaggeration to depict events. They usually contain a commercial reason. A common pattern of these games is the exaltation of triviality.

Reportage games can be compared to objective information on television or in a newspaper/magazine about an event. They do not allow online multiplayer play or even the creation of content by users. The reason for this is that a sub-genre of topical games must be produced and published quickly because the issues they address must remain 
topical. In general, reportage games focus on conveying information regarding specific cases in a fast and direct manner.

Documentary games seek to record an event, its space, and its actors for posterity. They are similar to reportage games, but more complex and with a more detailed process of in-depth analysis of an event. They provide a deeper and more interactive simulation of the event, entangling with causalities and correlations of the analyzed social phenomenon.

As for the second set of variables, the criteria correspond to the narratological paradigm set out by Aarseth (2012), composed of 4 technical indicators for the incorporation of narratives in their gameplay set (Table 3):

Table 3. Types of narratives applied in video games.

\begin{tabular}{|c|c|c|c|c|}
\hline \multirow[b]{2}{*}{ Observation } & \multicolumn{4}{|l|}{ Technical Indicators } \\
\hline & Video Game Worlds & Objects & $\begin{array}{l}\text { Non-Player } \\
\text { Characters (NPCs) }\end{array}$ & Events \\
\hline Narrative & $\begin{array}{l}\text {-No access } \\
\text {-Individual environment } \\
\text {-One-way environment } \\
\text {-Multiple-choice maze } \\
\text {-Open world with } \\
\text { secondary missions } \\
\text {-RPGs }\end{array}$ & $\begin{array}{l}\text {-No interaction } \\
\text {-Equippable } \\
\text {-Modifiable } \\
\text {-Destructible } \\
\text {-Craftable }\end{array}$ & $\begin{array}{l}\text {-NPCs with story } \\
\text {-NPCs with no } \\
\text { story, but } \\
\text { interactive }\end{array}$ & $\begin{array}{l}\text {-Mission Statement } \\
\text {-World of } \\
\text { secondary options } \\
\text {-Dynamic state of } \\
\text { the nuclei }\end{array}$ \\
\hline Ludics & Open world & Inventory & Full NPC's & $\begin{array}{l}\text { Game without } \\
\text { nuclei }\end{array}$ \\
\hline
\end{tabular}

Video game worlds

Narrative

*No access: this refers to video games that do not allow direct interaction with the content, in the same way as a visual novel, where the player has hardly any control over the actions and is not allowed to interact except in specific situations.

Individual environment: the player-controlled character has more freedom, but travels and conducts research to find a solution, on his own, to a situation in order to advance the story linearly.

Multiple-choice maze: the character can choose different actions that will lead to different endings within a video game, which also indicates a higher level of development within the video game to achieve different stories in different scenarios that can occur depending on the user's actions.

Open world with secondary missions: the character can move away from the storyline of the game to explore the scenery. Within this, secondary missions that are not mandatory, but that represent a bonus at the time that the user can perform and complete them, may also be found.

RPGs: the user takes on the role of living the character's story, and is introduced through a much more complex story in situations in which it is the user who takes a position in different situations, this indicator being for the most immersive kind of games.

Ludics

Open World: the development of the video game is extensive enough that the user can perform any action without restriction and even avoid the mainline plot of the game.

Objects

Narrative

No interaction: the character cannot perform any action with the objects within the video game, there are no options to perform, they is only decorative.

Equippable: the player can use the objects on the character, use them at that moment, or save them for later use. They also serve for solving puzzles that consist of transporting an object from one place to another. 
Modifiable: once equipped, the user can modify an object within the limitations of the video game, such as collecting clues to form, with each of them, the resolution to a question.

Destructible: elements that are within the scenario in which the course of the story takes place and that the character must destroy to obtain a reward, such as a box that can be broken to obtain medicine or a container where a clue for the resolution of a problem is found.

Craftable: separated elements built on a workbench or an element resulting from the fusion of others, which can be collected by the player.

Ludics

Inventory: the evolution of the equippable elements is about being able to store more than one object inside special lockers within the character that are of limited space, and that serve to store tools that help with the character's tasks.

NPCs

Narrative

NPCs with story: these NPCs provide greater depth to the story; they are non-player characters who have a system-predefined behavior to help, be antagonists, or contribute information to the character that is controlled by the player.

NPCs with no story, but interactive: these are non-player characters that develop as helpers or as antagonists, with the difference that they do not contribute to the plot of the game, but are only there to perform a specific task.

Ludic

Full NPCs: these do not interact with the character controlled by the user; they are part of the environment, giving the impression of a wider possible range of actions.

Events

Narrative

Mission Statement: the player has an objective that must be fulfilled in order to finish the game. In the world of video games, it is explained that there can be several goals, depending on the type of video game, but in the event of a mission, only the fulfillment of this goal will end the game.

World of secondary options: the player constantly has the option to deviate from the main path of the story to complete secondary events that can trigger different endings to a video game, depending on the level of complexity of the game in question.

Dynamic state of the nuclei: resolution and fulfillment of the objective will depend on the actions performed by the player; the cores are presented as final and valid points of a story told from different indicators in the game world.

Ludic

Game without nuclei: there is only a constant repetition in the video game, exemplified as a gain by the number of points obtained by playing the video game and by continuing the story which never ends; it is a loop that counts the points or successes and allows the user to know his margin or record.

For data collection, a theoretical-thematic coding was established (Auerbach and Silverstein 2003), where each indicator was justified by scientific publications that are oriented to a specific thematic, i.e., they come from the communication field (Ireton and Posetti 2018). Based on the two blocks of analysis criteria presented, 17 independent games connected to the COVID-19 pandemic were analyzed by examining both their informative purposes and their technical details that relate to the way the disease has been addressed globally.

Maintaining the validation system of the methodological procedure expressed by Lankoski and Björk (2015), each of the selected newsgames was verified according to two groups of variables through an online search, the first on the typology of newsgames, assessing components, actions, and goals, and the second referring to the technical aspects of the narrative. Secondly, the 17 newsgames were played by the 2 researchers for $1 \mathrm{~h}$ a day 
for 3 weeks, or $42 \mathrm{~h}$ in total, to exhaustively review each of the variables, thus obtaining the following results.

\section{Results}

\subsection{Editorial Games}

The video games that belong to this category are: COVID Courier, COVID-19 Shoot the virus dead!, 感染 COVID-19, and Covid-lifestyle. These games used a strategy of content dissemination and development within the context of the video game, and a structure of certain complexity; they provided the user with information regarding the pandemic that could be related to information provided by certain media, evidencing the didactic format of the video game, but keeping in the line of argument of the pandemic as a global problem that should be given importance and have as much information provided about it as possible.

COVID Courier indicates a story in a one-way environment. The complexity in its development demonstrates, chronologically, what happens to people when they are infected with COVID-19, and what to do to avoid contracting it. It uses the resource of the environment in only one way, to make vital the interaction with objects along the map, interacting with displayed and equippable information that leads to the use and sense of the object as the vaccine in real life; in the same way, the NPCs, although they do not have history, can be interacted with by the player.

In 感染 COVID-19, human being avoids the contagion of disease is revealed through dialogue. It follows an individual narrative environment in which the player cannot interact with objects within the game and the NPCs are only filler elements that do not contribute more than a decorative way to trace the mission.

COVID-19 Shoot the virus dead! and Covid-lifestyle focus on narrating in a playful, openworld, multiple-choice labyrinth environment. The player takes actions as an individual in the face of a pandemic, with the main mission mapped out, mixed with short options for secondary missions. The consequences of not following a biosecurity regulation include plot lines that lead the player to follow the mission, with destructible objects and NPCs without a story but with which the player can interact.

\subsection{Tabloid Games}

Covid Escape, COVID Nom Nom, Covid vs. Vacuna, Covid-run, COVID-19 Simulator, and Bio-hazard2020 were selected for this category. The common aspect between them is the maintenance of the line of giving complete importance to the "pandemic" theme, and the content is expressed in a much lighter, simpler way and with little depth within the contents, which, although they give importance to the COVID-19 theme in the development of the story of the video game, do not provide more outstanding information than what is observed in other types of available audiovisual material. No background indicates the actions to be taken in the face of the pandemic, but certain social behaviors, such as the proper use of masks, disinfection with alcohol, and social distancing, are framed.

For the cases of Covid Escape and COVID Nom Nom, which use simple environments, individual environments, or the one-way environment type, the content stands out because of the stuffed NPCs that decoratively use the environment, the depth of extra data concerning the pandemic, as well as the fact that the interaction with other environments that are separated from the main mission is impossible, restricting it to a single traced mission. Something similar happens in Covid-run and COVID-19 Simulator, in which an individual environment without the possibility of interacting with objects stands out, differing from the two previous ones because they use, in addition to data such as the correct behavior in society from a non-core point of view, NPCs without history, but with whom it is possible to interact.

Meanwhile, Covid vs. Vacuna and Bio-hazard 2020 have simple mechanics and are focused on reminding users about the health situation that is improving with the introduction of vaccines within a development of a multiple-choice maze. With simple mechanics 
and traced missions, the user assimilates the importance of vaccines for the character and, likewise, seeks to highlight the sense of how deadly vaccines are for a virus, thus focusing on directly combatting a virus with a vaccine.

\subsection{Reportage Games}

Quiz19, Coronakiller, COVID, and Covid Game were the video games selected for this category. Their themes vary greatly because they arose at a moment in which certain information about the pandemic was globally made public. Despite having a much more extensive background and attempting to deepen the information to be disclosed, they do not have much in common with each other except for the veracity of the media that was the base source for the creation of the video games. Among these video games, these are the most complete in terms of information, despite having a one-way environment with respect to the pandemic. Quiz 19, being a trivia-format game, highlights data about how the virus develops in the body, the most common symptoms, and what to do in case of feeling any ailment that could be related to COVID-19. It stands out in terms of content, despite not having interactions with objects or NPCs and having a dynamic state of cores.

Coronakiller was published before the mass development of vaccines, giving prominence to biosecurity methods and the importance of testing to determine the disease. Coronakiller, as a multiple-choice maze, bases its background information on the development of a virus within a living organism and how it evolves, and with a simple theme with traced missions, it stands out for the level of information presented in a didactic way that is contained and provided for the player.

COVID is a one-way video game in which themes of the importance of vaccines, social distancing, and the benefits associated with the use of face masks in places with people and in enclosed spaces such as corridors and/or rooms are developed. There are destructible, craftable, and equippable elements, which refers to tools that, throughout the game, provide information about the various methods of prevention, introducing the player to, and encouraging active attention toward, the actions that are performed with Non Players Characters (NPC's).

Covid Game is a game with a simple structure that encourages the user to learn about the behaviors of people for their protection against COVID-19. Its development is focused on avoiding NPCs that should not be approached too closely and that provide useful information about what to do and what not to do in a public environment.

\subsection{Documentary Games}

The selected games for this category were COVID-19 Pandemic-Infection Simulator, COVID Café, and The COVID-19. All of them necessitate more demanding research work, as they try to provide the player with as much useful information about the pandemic and the actions taken by authorities, social movements published by the media, and social behaviors that have been established at points of agglomeration of people using a playful style.

Within this classification, the most developed games in this area are COVID-19 Pandemic-Infection Simulator and Covid Café, which were launched after some countries reactivated their economies by opening leisure points, encouraging people to go out under strict biosecurity rules. COVID-19 Pandemic-Infection Simulator develops a multiple-choice and labyrinthine world, where the user monitors the behavior of a mass of people with the duty, as a means of communication, to warn and correct bad behaviors in public places such as crowds, and where, with vignettes, what can be generated and what should be allowed, such as the free movement of people who are at a safe distance from each other, is explained.

Covid Café focuses its attention on places of entertainment, such as a coffee shop, in which the speed of the workers is vital for the good flow of people to promote economic growth and, at the same time, for the avoidance of crowds of people that can cause the closure of the premises or contagion by crowds. 
Meanwhile, The COVID-19 stands out for the emphasis it places on the fulfillment of simple tasks increased by the action of the rules to which it adapts to society, such as public places and social distancing. The common objects that the player can inventory are placed as a clear reference to the behavior of people during the return to the free transit of people, which become NPCs without history but with which the player can interact if the player gets too close, which makes the mission fail.

\subsection{Relationship between Narrative Aspects and Game Interpretation}

For the analysis of the proposed narrative content (Table 3) from which the platforms are taken, Itch.io and Gamejolt were used for the development of the research, which is characterized by hosting the independent creations of users of the site, allowing us to develop our observation criteria, which are detailed in Tables 1 and 2, as well as in the table proposed by Aarseth (2012) (Table 3). The criteria under which our study will be conducted is detailed and oriented to the narrative scope and based on what allows us to differentiate between the experience within the environment and what is provided for the user of video games about the COVID-19 pandemic thematic.

Games such as COVID-19 Shoot the virus dead!, 感染 COVID-19, and COVID Courier provide one-way environments in a mapped-out mission without interactions with objects and, in the case of COVID Courier, allow for interactions with NPCs that do not have a story. Meanwhile, Covid Lifestyle differs by having an individual environment, but with equippable objects, where there are NPCs that, although lacking a story, can be interacted with.

Covid-run, Covid Escape, COVID Nom Nom, and Covid vs. Vacuna, are easy games that are quite simple but that obey an informative mechanic about COVID-19; in this way, they focus on a one-way environment where there are no usable objects; however, there are collectibles that indicate achievements that users can obtain as they advance in the game. There are no NPCs in these games; however, there is a more modifiable range because there are secondary options that give users the possibility of different routes to reach the end. While COVID-19 Simulator and Bio-hazard2020 do not have these alternate routes to a different end, their development is common with the previous exposed.

In the case of COVID by Martin Herrera, Quiz19, and Coronakiller, their environment has little detail in terms of the depth of the story, and follows the concept of a one-way environment, which faces a plotted mission with destructible objects where there are no NPCs. However, despite having the same line of events, games such as Covid Game have filler NPCs that help the user focus more on the story, without directly affecting it.

Finally, in the case of The COVID-19, COVID Café, and COVID-19 Pandemic-Infection Simulator, they have more complex mechanics, where the level of detail and development is deepened to give a more detailed type of information regarding the subject, approaching it from two different themes, the individual environment, at first, the equippable objects in the case of The COVID-19 and COVID-19 Pandemic-Infection Simulator, and COVID Café. While the first two games do not make use of NPCs, COVID Café has NPCs without story but with which you can provide interaction. In all three cases, the mission is outlined; however, the way the mission is approached by each game varies, having as points of conjunction the type of theme, the depth of the exemplified information, and the level of detail at a technical level.

We affirm, then, that the indie newsgames can offer ample possibilities for storytelling, as long as the rules proposed by their game are respected, in the same way that we can read stories about how the social conventions of a time, in this case, conventions related to COVID-19, have been inscribed in order to understand the world of the culture that sustains them through the linkage between games and narratives.

\section{Conclusions}

The 17 newsgames analyzed in this research and that correspond to the pandemic theme show that $35 \%-6 / 17$-are tabloid games. This type of newsgame seeks to prioritize 
immediacy over quality; that is to say, tabloid games put speed first, boosting the creativity and sensationalism of a news item, hoping that the short duration of the covered news item generates enough impact and interactions without a need to invest excessive time in the development and design of dynamics, mechanics, and playful interfaces, focusing on simple issues such as alcohol sanitization and the use of masks.

On the other hand, and with fewer games created on these independent platforms, are the documentary games, which comprise $18 \%-3 / 17-$ of the games selected for this study. The games belonging to this category aim to build a holistic view of the pandemic, focusing on teaching and raising awareness of prevention measures and public policies formulated to mitigate the health crisis. At the same time, documentary games are games that are more elaborate in terms of design, interface, and graphics; therefore, they do not focus on a specific episode of the health crisis but take into account general assessments expressed in the media to mitigate the effects of COVID-19.

Likewise, from these results, it can be elucidated that the independent newsgames made towards the contextualization of the pandemic contain two approaches: the first one seeks to provide additional information on news that has become viral and has had a strong impact on society, such as the extension of the contagion, the vulnerability of the elderly, and the confinement and ease of transmission of the virus. The second approach is organized to review the biosecurity rules, specifying social distancing, the use of alcohol, masks, and hand washing, among others.

As for the second specific objective, which is configured based on narratological elements, most of the games tend to be short in length, individual, with a single storyline and a simple interface format with playful, interactive actions and standard-quality graphics, similar to Doom Eternal running at 1080p and 60 FPS.

In short, newsgames are characterized by their capacity to serve as a space for reproducing informative discourses, using their persuasive and stimulating capacities to bring the message closer to other audiences (De Santis and Armendáriz 2020). The same situation can be evidenced with those made in the context of the pandemic; however, the "indie" industry contains, as an added value, the quality of not being governed based on an editorial line; it can argue, counter-argue, exaggerate, and simulate a series of aspects that could be censored by the owners of the media. Independent newsgames are a reference for free will that is configured towards the interests of the public and not of the owners of the media. It is, thus, recommended that future research should delve deeper into the use of newsgames in other contexts, knowing the public's perception of their use and the developers' opinion on their technical section.

Author Contributions: Conceptualization, J.M.-R. and A.T.-T.; methodology, A.T.-T.; formal analysis, A.T.-T.; investigation, J.M.-R.; resources, A.T.-T.; writing—original draft preparation, J.M.-R.; writing - review and editing, A.T.-T. All authors have read and agreed to the published version of the manuscript.

Funding: This research received no external funding.

Institutional Review Board Statement: Not applicable.

Informed Consent Statement: Not applicable.

Data Availability Statement: Not applicable.

Acknowledgments: Gamelab-UPS Research Group, Universidad Politécnica Salesiana, Ecuador.

Conflicts of Interest: The author declares no conflict of interest.

\section{References}

Aarseth, Espen. 2012. A narrative theory of games. Paper presented at the international conference on the foundations of digital Games, Raleigh, NC, USA, May 29-June 1.

Alarcia, Diego. 2015. Plague Inc.: Pandemias, videojuegos y enseñanza-aprendizaje de las Ciencias Sociales. Enseñanza de las Ciencias Sociales 14: $135-42$.

Auerbach, Carl, and Louise Silverstein. 2003. Qualitative Data: An Introduction to Coding and Analysis. Nueva York: NYU Press. 
Belli, Simone, and Sara Olivé. 2008. Reseña de "Los videojuegos" de Adriana Gil y Tere Vida Mombiela. Athenea Digital. Revista de Pensamiento e Investigación Social 13: 285-90. [CrossRef]

Bogost, Ian, Simon Ferrari, and Bobby Schweizer. 2012. Newsgames: Journalism at Play. Cambridge: Mit Press.

Costumero, Xandra. 2021. Los videojuegos como alternativa a los problemas conectivos de la pandemia. Temas para el Debate 313: 40-42.

De Santis, Andrea, and David Armendáriz. 2020. Jugando a la Pandemia entre los newsgames y la simulación lúdica. Estudios pedagógicos (Valdivia) 46: 123-40. [CrossRef]

Ferreira, Gil, and Susana Borges. 2020. Media and Misinformation in Times of COVID-19: How People Informed Themselves in the Days Following the Portuguese Declaration of the State of Emergency. Journalism and Media 1: 108-21. [CrossRef]

Gavoto, Leticia, Diego Terceiro, and Sergio Terrasa. 2020. Pantallas, niños y confinamiento en pandemia: Debemos limitar su exposición? Evidencia, Actualización en la Práctica Ambulatoria 23: e002097. [CrossRef]

Gekker, Alex. 2012. Health games. Paper present at the International Conference on Serious Games Development and Applications, Berlin, Germany, September 26-29.

Gómez-García, Salvador, and José-Agustín Carrillo-Vera. 2020. El discurso de los newsgames frente a las noticias falsas y la desinformación: Cultura mediática y alfabetización digital. Revista Prisma Social 30: 22-46.

Gómez García, Salvador, and Nuria Navarro Sierra. 2013. Videojuegos e Información. Una aproximación a los newsgames españoles como nueva óptica informativa. Icono 14: 31-51. [CrossRef]

Hobbs, Reneé. 2021. Media Literacy in Action: Questioning the Media. Lanham: Rowman \& Littlefield Publishers.

Igado, Manuel, Amor Rodríguez, and Ignacio Aguaded. 2013. La realidad de los videojuegos ¿una nueva dimensión social? Pulso: Revista de Educación 36: 191-203.

Ireton, Cherilyn, and Jane Posetti. 2018. Journalism, Fake News \& Disinformation: Handbook for Journalism Education and Training. Paris: UNESCO Publishing.

Lankoski, Patri, and Staffan Björk. 2015. Game Research Methods: An Overview. Dartmouth: ETC Press.

Marín Gutiérrez, Isidro, Mónica Hinojosa Becerra, and Javier Ruiz San Miguel. 2018. Newsgames en Ecuador. Correspondencias E Análisis 8: 121-45.

Marín, Verónica, and María García. 2005. Los videojuegos su capacidad didáctico-formativa. Pixel-Bit. Revista de Medios y Educación 26: 113-19.

Montes, Jairo, Solanlly Ochoa, David Baldeón, and Mariana Bonilla. 2018. Videojuegos educativos y pensamiento científico: Análisis a partir de los componentes cognitivos, metacognitivos y motivacionales. Educación y Educadores 21: 388-408. [CrossRef]

Ohannessian, Robin, Sarina Yaghobian, Pierre Verger, and Philippe Vanhems. 2016. A systematic review of serious video games used for vaccination. Vaccine 34: 4478-83. [CrossRef] [PubMed]

Requena, Esther, and Karen McMullin. 2015. Videojuegos para la inclusión educativa. Digital Education Review 27: $122-37$.

Romero-Rodríguez, Luis, and Angel Torres-Toukoumidis. 2018. Con la información sí se juega: Los newsgames como narrativas inmersivas transmedias. In Gamificación en Iberoamérica Experiencias desde la Comunicación y la Educación. Edited by Angel Torres-Toukoumidis and Luis Romero Rodríguez. Ecuador: Abya-Yala, pp. 36-52.

Sampieri, Roberto, Carlos Fernández, and Pilar Baptista. 2012. Metodología de la Investigación. Mexico: McGraw-Hill.

Serrano Vázquez, Irene. 2015. Participatory Practices and Journalism: The Impact of User-Generated Content in Making News. Ph.D. thesis, Concordia University, Montreal, QC, Canada.

Sicart, Miguel. 2008. Newsgames: Theory and design. Paper presented at the International Conference on Entertainment Computing, Pittsburg, CA, USA, September 25-27.

Sierra, Nuria Navarro, and Raquel Quevedo Redondo. 2020. Ludificación informativa en tiempos de pandemia: Newsgames y la Covid-19. Revista ComHumanitas 11: 56-74. [CrossRef]

Smith, Julia, Nathan Sears, Ben Taylor, and Madeline Johnson. 2020. Serious games for serious crises: Reflections from an infectious disease outbreak matrix game. Globalization and Health 16: 1-8. [CrossRef] [PubMed]

Torres Fernández, David, Emanuel Blanca Moya, and Rolando Pérez Sánchez. 2021. Inmersión y activación de estados emocionales con videojuegos de realidad virtual. Revista de Psicología 39: 531-51. [CrossRef]

Torres-Toukoumidis, Angel, and Luis Romero-Rodríguez. 2018. Aprender jugando. La gamificación en el aula. In Educar Para Los Nuevos Medios. Edited by Rosa García, Amor Pérez-Rodríguez and Angel Torres-Toukoumidis. Ecuador: Abya-Yala, pp. 61-72.

Torres-Toukoumidis, Angel, Vladimir Robles-Bykbaev, Mario Cajamarca, Luis Romero-Rodríguez, Janette Chaljub, and Juan Pablo Salgado. 2019. Gamified platform framing for entrepreneur competencies. Journal of Entrepreneurship Education 22: 1-9. 